\title{
Retardation of ovarian growth in male-sterile mice carrying an autosomal translocation
}

\author{
URSUlA MITTWOCH, SHANTHA MAHADEVAIAH, AND MARY B OLIVE \\ From the Department of Genetics and Biometry, The Galton Laboratory, University College London, \\ Wolfson House, London NWI $2 H E$
}

SUMMARY Ovarian volumes in 3- and 5-day-old mice heterozygous for the $\mathrm{t}(11 ; 19) 42 \mathrm{H}$ translocation were found to be smaller than those of normal controls. Comparisons between litter mates suggested a slight increase in body weight of the translocation bearers and this effect increased the difference in relative ovarian volumes between $\mathrm{t} 42 \mathrm{H} /+$ mice and controls. It is suggested that the differential effect of the translocation on fertility in males and females might be the result of the higher meiotic requirements inherent in spermatogenesis.

Autosomal translocations are a cause of male sterility in mice as well as men. Lyon and Meredith ${ }^{1}$ were the first to show that certain translocations that did not involve sex chromosomes caused sterility in male mice, while females were fertile, albeit with reduced litter size. Searle et $a l^{2}$ described eight autosomal translocations that are maintained through female carriers, the males being sterile. Testis weight is low and spermatogenesis is arrested at different stages characteristic for any particular translocation.

An apparently similar situation has been described in man. ${ }^{3}$ Three brothers, carriers of a balanced reciprocal translocation between chromosomes 9 and 22 , were sterile. A testicular biopsy in one of them revealed spermatogenesis until metaphase I but few spermatids and no spermatozoa. Chain quadrivalents were present at diakinesis. The translocation had been inherited from the mother in whom oogenesis appeared to proceed normally.

The question arises of why the same translocation causes meiotic arrest in males but not in females. Does the altered chromosome constitution affect testicular but not ovarian development or could the primary effect be similar in both sexes with females showing reduced sensitivity?

We have measured ovarian volumes in immature mice carrying a balanced autosomal translocation, $t(11 ; 19) 42 \mathrm{H} /+,^{2}$ and found them to have reduced ovary size and a reduced ratio of ovarian volume to body weight.

\section{Materials and methods}

Female mice heterozygous for the $\mathrm{t} 42 \mathrm{H}$ translocation Received for publication 9 February 1981 were mated to $(\mathrm{C} 3 \mathrm{H} \times 101) \mathrm{F} 1$ males. Young mice, aged either 3 or 5 days, were weighed before being killed by decapitation.

Presence or absence of the translocation was assessed in one of two ways. The mothers of five females were heterozygous for the wavy-coat allele of rex $\left(R e^{w c}\right)$, which is located on chromosome 11 and gives a recombination frequency of about $9 \%$ with the breakpoint of the translocation. ${ }^{4}$ Mice carrying this allele can be identified shortly after birth by their abnormally bent whiskers. ${ }^{5}$ The remaining litters totalling 19 mice did not segregate for $R e^{w c}$ and chromosomes were analysed from liver preparations by a modification of the method of Eicher and Washburn ${ }^{6}$ (Evans, 1980, personal communication). The $\mathrm{t} 42 \mathrm{H}$ translocation has two markers: chromosome $11^{19}$ has a conspicuous constriction and chromosome $19^{11}$ is shorter than any normal chromosome (fig 1). At least two cells were analysed from each mouse.

In order to measure ovarian volumes, the two ovaries were dissected out, fixed in Bouin's solution, and prepared for serial sectioning at $7 \mu \mathrm{m}$. Haematoxylin and eosin were used for staining. Areas of sectioned ovaries were measured by a counting method using a modified Whipple eyepiece micrometer (Graticules Ltd) as described previously. ${ }^{7}$ The method involves counting squares overlying the sectioned ovaries, taking care to randomise partially overlying squares. Absolute volumes were calculated using a stage micrometer.

\section{Results}

Values of mean ovarian volumes of right and left ovaries in relation to body weight in $\mathrm{t} 42 \mathrm{H} /+$ and 


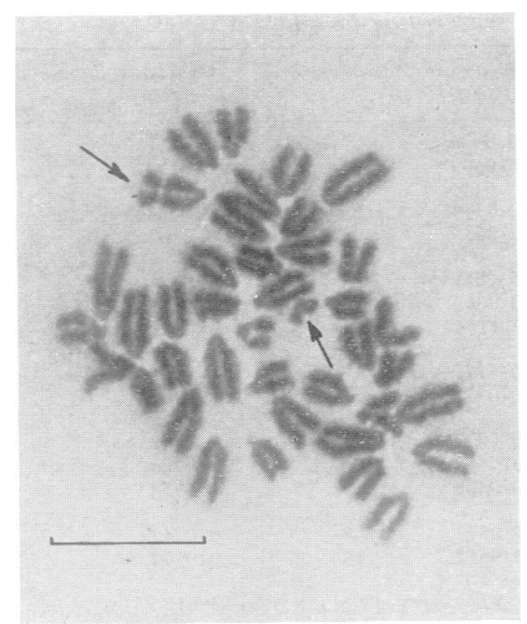

FIG 1 Chromosomes of $\mathrm{t} 42 \mathrm{H} /+$ female mouse showing two markers. Arrows point to chromosome $11^{19}$ (constriction) and $19^{11}$ (small). Length of bar $=0.01 \mathrm{~mm}$.

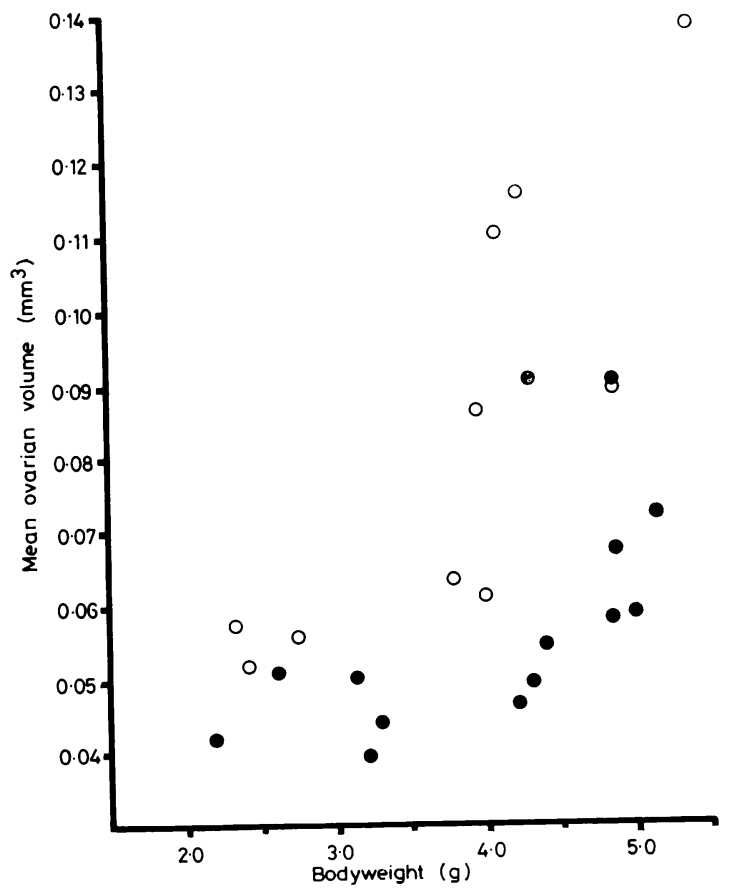

FIG 2 Ovarian volumes and body weight in normal and $\mathrm{t42H} /+$ mice. O normal, $\bullet \mathrm{t} 42 \mathrm{H} /+$. control $+1+$ mice are shown in fig 2 . Analysis of covariance resulted in $t=4 \cdot 14$, which has a probability of less than 0.001 , thus confirming the visual impression that the ovaries of $t 42 \mathrm{H} /+$ mice are smaller in relation to body weight than those of $+/+$ mice.

Additional information on the effect of the translocation on ovarian development and body weight is obtained by comparisons between litter mates. Fourteen of the mice came from litters containing at least one female with and one without the translocation (table).

The significance of the differences between translocation mice and controls was tested on the null hypothesis that the values for $\mathrm{t} 42 \mathrm{H}$ mice did not differ from the means of their respective litters, using the formula

$$
\frac{\Sigma \mathrm{Sx}-\Sigma \mathrm{E}}{\sqrt{\Sigma \mathrm{V}_{\mathrm{Sx}}}}
$$

where $S x=$ sum of body weights of $t 42 \mathrm{H}$ females in each litter

$\mathrm{Nx}=$ number of $\mathrm{t} 42 \mathrm{H}$ females in each litter

$\mathrm{S}=$ sum of body weights of all females in each litter

$\mathbf{N}=$ number of all females in each litter

$\mathrm{E}=$ expected sum of body weights of t42 $\mathrm{H}$ females in each litter

$=\mathrm{SNx} / \mathrm{N}$

$\mathrm{V}=$ variance of body weights in each litter

$\mathbf{V}_{\mathbf{S x}}=$ variance of $\mathbf{S x}$

$$
=\mathrm{VNx}(\mathrm{N}-\mathrm{Nx}) / \mathrm{N}
$$

and similarly for the other variables shown in the table.

The results indicate that the differences are significantly larger than their standard errors and suggest that the $\mathrm{t} 42 \mathrm{H} /+$ mice differ from their normal litter mates in having slightly increased body weights and smaller ovarian volumes.

\section{Discussion}

In the male, the $42 \mathrm{H}$ translocation results in breakdown of meiosis: $\mathrm{t} 42 \mathrm{H} /+$ spermatocytes start to die in stage IV, and finally disappear in stage IX (mid-pachytene) of the cycle of the seminiferous epithelium. ${ }^{8}$ Adult testis weight is about a quarter of the normal. ${ }^{2}$

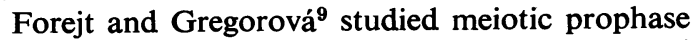
in three autosomal translocations and observed non-random contact of the translocation configuration with the $\mathrm{C}$ bands of the $\mathrm{X}$ chromosome. The authors postulated interference with the inactivation of the $\mathrm{X}$ chromosome as a cause for spermatogenic arrest. A similar chromosome association in female 
TABLE Body weights and ovarian volumes in female mice from litters segregating for $\mathbf{t 4 2 H}$

\begin{tabular}{|c|c|c|c|c|c|}
\hline Litter No & Mouse & Chromosomes & $\begin{array}{l}\text { Body weight } \\
(g)\end{array}$ & $\begin{array}{l}\text { Mean ovarian volume } \\
\left(\mathrm{mm}^{3}\right)\end{array}$ & $\begin{array}{l}\text { Ovarian volume/body weight } \\
\left(\mathrm{mm}^{3} / \mathrm{g}\right)\end{array}$ \\
\hline 4 & $\begin{array}{l}15 \\
16\end{array}$ & $\begin{array}{l}\mathrm{t} 42 \mathrm{H} \\
+\end{array}$ & $\begin{array}{l}4 \cdot 3 \\
4 \cdot 0\end{array}$ & $\begin{array}{l}0.0494 \\
0.0609\end{array}$ & $\begin{array}{l}0.0115 \\
0.0152\end{array}$ \\
\hline 7 & $\begin{array}{l}25 \\
26\end{array}$ & $\begin{array}{l}\mathrm{t} 42 \mathrm{H} \\
+\end{array}$ & $\begin{array}{l}4 \cdot 4 \\
3 \cdot 8\end{array}$ & $\begin{array}{l}0.0544 \\
0.0635\end{array}$ & $\begin{array}{l}0.0124 \\
0.0167\end{array}$ \\
\hline 10 & $\begin{array}{l}32 \\
33 \\
34\end{array}$ & $\begin{array}{l}\mathbf{t} 42 \mathrm{H} \\
+ \\
+\end{array}$ & $\begin{array}{l}4 \cdot 73 \\
3 \cdot 94 \\
4 \cdot 23\end{array}$ & $\begin{array}{l}0.0669 \\
0.0862 \\
0.1154\end{array}$ & $\begin{array}{l}0.0141 \\
0.0219 \\
0.0273\end{array}$ \\
\hline 12 & $\begin{array}{l}38 \\
39\end{array}$ & $\underset{t 42 H}{+}$ & $\begin{array}{l}5 \cdot 41 \\
5 \cdot 13\end{array}$ & $\begin{array}{l}0.1379 \\
0.0722\end{array}$ & $\begin{array}{l}0.0255 \\
0.0141\end{array}$ \\
\hline 13 & $\begin{array}{l}40 \\
41 \\
43\end{array}$ & $\begin{array}{l}\mathrm{t} 42 \mathrm{H} \\
+ \\
\mathrm{t} 42 \mathrm{H}\end{array}$ & $\begin{array}{l}3 \cdot 17 \\
2 \cdot 74 \\
3 \cdot 25\end{array}$ & $\begin{array}{l}0.0373 \\
0.0558 \\
0.0500\end{array}$ & $\begin{array}{l}0.0118 \\
0.0204 \\
0.0154\end{array}$ \\
\hline$\Sigma S x-\Sigma E^{*}$ & & & $2 \cdot 12$ & $-1 \cdot 92$ & $-2 \cdot 51$ \\
\hline p & & & 0.05 & 0.05 & 0.01 \\
\hline
\end{tabular}

*See Results section.

meiosis would not be expected to have deleterious effects since both $\mathrm{X}$ chromosomes are active during oogenesis. ${ }^{9}$ Our finding that the translocation is associated with retardation of ovarian development weakens this hypothesis, although it does not disprove it.

The other suggestion implicit in the data, that the $\mathrm{t} 42 \mathrm{H} /+$ karyotype causes a small increase in the body weight of females, although clearly in need of confirmation, raises the possibility of a systemic effect of the translocation on processes of growth and development. Theoretically this could be the result of either position effect or a possible loss of a small amount of chromosomal material resulting from the translocation. It may be relevant that Russell and Montgomery ${ }^{10}$ observed decreased weights in female mice heterozygous for various $X$;autosome translocations.

The adverse effect on ovarian growth suggests that the $\mathrm{t} 42 \mathrm{H}$ translocation might exert similar effects on spermatogenesis and oogenesis which result in sterility in males while females are fertile. The reason could perhaps be sought in the disparate numbers of male and female gametes required for fertilisation, when many millions of spermatocytes need to complete meiosis in order to fertilise a single egg. Also, the time available for meiosis is greater in females than in males. The data do not support the argument by Dawkins ${ }^{11}$ that because the egg is larger than the sperm a mother's investment in a child is greater than the father's. On the basis of simple arithmetical considerations regarding relative gamete sizes and numbers in mammals, one would conclude that the investment in spermatozoa is greater than that in eggs. This conclusion is borne out by numerous chromosome abnormalities in $\vec{\theta}$ mammals that result in breakdown of spermato $\infty$ genesis while being compatible with reproduction the female.

We thank Dr A G Searle and Mr C V Beechey for supplying the mice and for discussion, Dr Gillian $M$ Truslove and Mrs Diane Kyriacou for maintaining the mice and for discussion, Drs E P Evans and $M$ Burtenshaw for help with cytogenetic techniques, Professor C A B Smith for help with statistical analysis, and Mr A J Lee for drawing the diagram. The work was supported by a project grant from the Medical Research Council.

\section{References}

1 Lyon MF, Meredith R. Autosomal translocation causing male sterility and viable aneuploidy in the mouse. Cytogenetics 1966;5:335-54.

2 Searle AG, Beechey CV, Evans EP. Meiotic effects in chromosomally derived male sterility of mice. Ann Biol Anim Biochim Biophys 1978;18(2B):391-8.

3 Chandley AC, Christie S, Fletcher J, Frackiewicz A Jacobs PA. Translocation heterozygosity and associated subfertility in man. Cytogenetics 1972;11:516-33.

4 Beechey CV, Searle AG. Personal communication. Mouse News Letter 1976;54:39.

5 Searle AG. Personal communication. Mouse News Letter 1968;39:25.

6 Eicher EM, Washburn LL. Assignment of genes to regions of mouse chromosomes. Proc Natl Acad Sci USA $1978 ; 75: 946-50$. 
7 Mittwoch U, Mahadevaiah S. Additional growth-a link between mammalian testes, avian ovaries, gonadal asymmetry in hermaphrodites and the expression of $\mathrm{H}-\mathrm{Y}$ antigen. Growth 1980;44:287-300.

${ }^{8}$ de Boer P, Searle AG. Summary and synthesis. Workshop on Chromosomal Aspects of Male Sterility in Mammals. $J$ Reprod Fertil 1980;60:257-65.

9 Forejt J, Gregorová S. Meiotic studies of translocations causing male sterility in the mouse. I. Autosomal reciprocal translocations. Cytogenet Cell Genet 1977;19: 159-79.

10 Russell LB, Montgomery CS. Comparative studies on
$\mathrm{X}$-autosome translocations in the mouse. I. Origin, viability, fertility, and weight of five $\mathrm{T}(\mathrm{X} ; 1)$ 's. Genetics 1969;63:103-20.

11 Dawkins R. The selfish gene. Oxford: Oxford University Press, 1976.

Requests for reprints to Dr U Mittwoch, Department of Genetics and Biometry, The Galton Laboratory, University College London, Wolfson House, 4 Stephenson Way, London NW1 2HE. 
diseases and to make these cells available at a nominal charge to all legitimate investigators. We welcome any appropriately characterised cell cultures for repository inclusion. For further information and cell strain contribution write to: Drs
H Goldman or Sergio Pena, The Cell Repository of Neuromuscular Diseases, deBelle Laboratory for Biochemical Genetics, Montreal Children's Hospital, 2300 Tupper Street, Montreal, Quebec, Canada H3H 1 P3.

\section{Correction}

In the article 'Retardation of ovarian growth in male-sterile mice carrying an autosomal translocation' by Mittwoch et al (J Med Genet 1981 ;18: 414-7), the mouse translocations were printed throughout using human instead of mouse cytogenetics nomenclature, that is, $t$ instead of $T$. We apologise for this error. 